\title{
PENGARUH PENGGANTIAN SEBAGIAN RANSUM BASAL DENGAN TEPUNG DAUN PEPAYA (Carica papaya $L$ ) TERHADAP PERFORMANS AYAM PEDAGING
}

\author{
Sintia Tempomona, Betty Bagau*, Fenny R. Wolayan, Mursye N. Regar \\ Fakultas Peternakan Universitas Sam Ratulangi Manado, 95115
}

\begin{abstract}
ABSTRAK
Penelitian ini bertujuan untuk mengetahui sejauh mana penggantian sebagian ransum basal dengan tepung daun pepaya yang diukur melalui performans ayam pedaging. Menggunakan 100 ekor ayam pedaging umur 2 minggu dengan rataan bobot badan awal 278,75 g. Rancangan yang digunakan adalah Rancangan Acak Lengkap (RAL) yang terdiri dari 4 perlakuan 5 ulangan. Susunan perlakuan sebagai berikut : $\mathrm{R} 0=100 \%$ ransum basal $(\mathrm{RB})+0 \%$ Tepung Daun Pepaya (TDP), R1=95\% ransum basal + $5 \%$ TDP, R2 $=90 \%$ ransum basal $+10 \%$ TDP, R3 $=85 \%$ ransum basal $+15 \%$ TDP. Hasil analisis keragaman menunjukkan bahwa penggantian sebagian ransum basal dengan tepung daun papaya memberikkan pengaruh berbeda nyata $(\mathrm{P}<0,05)$ terhadap konsumsi ransum, pertambahan bobot badan dan konversi ransum. Berdasarkan hasil penelitian ini dapat disimpulkan bahwa penggunaan tepung daun pepaya dapat menggantikan sebagian ransum sampai level $5 \%$.
\end{abstract}

Kata Kunci : Performans, Tepung Daun Pepaya, Ayam Pedaging

\footnotetext{
*Korespondensi (corresponding Author)

Email: bettybagau@unsrat.ac.id
}

\section{ABSTRACT}

EFFECT OF SUBTITUTION OF BASIC RATIONS WITH PAPAYA LEAF MEAL ON BROILER PERFORMANCE. This research aims to know the effect of substitution of basic rations with papaya leaf meal on broiler performance. Using 100 broiler chickens aged 2 weeks with an initial weight rate of $278.75 \mathrm{~g}$. The design used was complete random design (CRD) consisting of 4 treatments and 5 replications. The arrangement of the treatment was as follows: $\mathrm{R} 0=100 \%$ basal ration $(\mathrm{RB})+0 \%$ papaya leaf meal $(\mathrm{PLM}), \mathrm{R} 1=95 \%$ basal ration $+5 \%$ PLM, R2 $=90 \%$ basal ration + $10 \%$ PLM, R3 $=85 \%$ basal ration $+15 \%$ PLM. The results of the analysis of variance showed that the replacement of a portion of basal rations with papaya leaf meal had a significantly different $(\mathrm{P}<0.05)$ on feed intake, daily weight gain and feed conversion. Based on the results of this study, It can be concluded that the using of papaya leaf meal can replace a portion of ration until 5\% level.

Keywords: Performance, papaya leaf meal, broiler chickens 


\section{PENDAHULUAN}

Permintaan ayam pedaging yang semakin tinggi menyebabkan semakin berkembangnya usaha peternakan ayam pedaging. Ayam pedaging merupakan salah satu jenis unggas penghasil daging yang potensial, efisiensi pakan cukup tinggi, masa pemeliharaanya relatif singkat dan pertumbuhannya cepat, 5 - 6 minggu sudah mencapai berat jual ideal, dengan demikian ayam pedaging harus memiliki kondisi yang baik terutama dalam fase pertumbuhan.

Keberhasilan suatu usaha peternakan ayam pedaging sangat dipengaruhi oleh pakan yang digunakan dan dimanfaatkan oleh ternak. Mengatasi masalah tersebut, salah satu cara yang dapat dilakukan yaitu dengan memanfaatkan limbah pertanian yang tidak dimanfaatkan. Salah satu limbah pertanian yang dapat dimanfaatkan yaitu daun pepaya yang merupakan sumber daya lokal.

Hasil analisis laboratorium nutrisi ternak ruminansia dan kimia makanan ternak UNPAD menunjukkan bahwa daun pepaya mengandung zat - zat makanan, diantaranya: protein $18.14 \%$, lemak kasar $1.67 \%$, serat kasar $12.67 \%$, abu $10.62 \%$, air $7,68 \%$, Ca $4,57 \%$, phospor $0,38 \%$, dan energi bruto $2476.5 \mathrm{kkal} / \mathrm{kg}$.
Komposisi zat makanan yang terdapat pada tepung daun pepaya memungkinkan pemanfaatanya sebagai salah satu bahan pakan ternak ayam pedaging. Ternak ayam pedaging membutuhkan ransum dengan kandungan protein $18-23 \%$ dan energi $2800-3200$.

Berdasarkan latar belakang tersebut, telah dilakukan penelitian tentang pengaruh penggantian sebagian ransum basal dengan tepung daun pepaya terhadap konsumsi pakan, pertambahan berat badan, dan nilai konversi pakan pada broiler.

\section{MATERI DAN METODE PENELITIAN}

Penelitian dilaksanakan dikandang unggas Fakultas Peternakan Universitas Sam Ratulangi Manado, waktu pelaksanaan 26 Oktober - 07 Desember 2018. Penelitian ini menggunakan ternak ayam pedaging unsexed, umur 1 hari (DOC), sebanyak 100 ekor. Setelah 2 minggu ayam diberi pakan perlakuan dengan rata - rata bobot badan awal 278,75 g. Kandang yang digunakan dalam penelitian ini yaitu kandang sistem battery ukuran 60x 45x $45 \mathrm{~cm}$ sebanyak 20 unit. Tiap unit kandang ditempatkan 5 ekor ternak ayam pedaging yang dilengkapi dengan tempat makan dan minum. Perlengkapan lain yang digunakan selama penelitian yaitu: wadah pencampur 
Tabel 1. Komposisi Nutrien Bahan Pakan Penyusun Ransum

\begin{tabular}{lcccccc}
\hline Bahan Pakan & $\begin{array}{c}\text { Protein } \\
(\%)\end{array}$ & $\begin{array}{c}\text { Kasar } \\
(\%)\end{array}$ & $\begin{array}{c}\text { Lemak } \\
(\%)\end{array}$ & $\begin{array}{c}\mathrm{Ca} \\
(\%)\end{array}$ & $\begin{array}{c}\text { P } \\
(\%)\end{array}$ & $\begin{array}{c}\mathrm{EM} \\
\mathrm{kcal} / \mathrm{kg}\end{array}$ \\
\hline Jagung* & 8,01 & 3,45 & 7,71 & 0,17 & 0,7 & 2865,75 \\
Tepung Ikan* & 63,6 & 0,5 & 9,3 & 5,81 & 3,23 & 2830 \\
Tepung Kedelai* & 42,02 & 6,4 & 13,22 & 0,21 & 0,65 & 3603 \\
Bungkil .Kelapa* & 20,55 & 15,9 & 15,07 & 0,21 & 0,49 & 3724,5 \\
Dedak * & 8,36 & 16,5 & 6,58 & 0,18 & 0,84 & 2564,25 \\
Tepung daun & 18,14 & 12,7 & 1,67 & 4,57 & 0,38 & 2476,5 \\
pepaya** & 0 & 0 & 0 & 5,38 & 1,44 & 0 \\
Top Mix & 0 & 0 & 100 & 0 & 0 & 88,12 \\
Minyak & & & & & & \\
\hline Sumber * Salo
\end{tabular}

Sumber: * Salombre et al. (2018)

** Analisis Laboratorium Nutrisi Ternak \& Kimia Makanan Ternak, UNPAD (2018).

Tabel 2. Komposisi Ransum Basal

\begin{tabular}{lrrrrrrr}
\hline Bahan Pakan & $\begin{array}{r}\text { Jumlah } \\
(\%)\end{array}$ & $\begin{array}{r}\text { Protein } \\
(\%)\end{array}$ & $\begin{array}{r}\text { SK } \\
(\%)\end{array}$ & $\begin{array}{c}\text { LK } \\
(\%)\end{array}$ & $\begin{array}{r}\text { Ca } \\
(\%)\end{array}$ & $\begin{array}{r}\text { P } \\
(\%)\end{array}$ & $\begin{array}{r}\text { EM } \\
(\mathrm{kcal} / \mathrm{kg})\end{array}$ \\
\hline Jagung & 50 & 4,01 & 1,73 & 3,86 & 0,09 & 0,35 & 1432,88 \\
Tepung Ikan & 15 & 9,54 & 0,08 & 1,40 & 0,87 & 0,48 & 424,5 \\
Tepung Kedelai & 14 & 5,88 & 0,90 & 1,85 & 0,03 & 0,09 & 504,42 \\
Bungkil .Kelapa & 14 & 2,88 & 2,22 & 2,11 & 0,03 & 0,07 & 521,43 \\
Dedak Halus & 5,5 & 0,46 & 0,91 & 0,36 & 0,01 & 0,05 & 141,03 \\
Top Mix & 0,5 & 0 & 0 & 0 & 0,03 & 0,01 & 0 \\
Minyak & 1 & 0 & 0 & 1 & 0 & 0 & 88,12 \\
\hline Jumlah & 100 & 22,77 & 5,84 & 10,58 & 1,06 & 1,05 & 3112,37 \\
\hline
\end{tabular}

Tabel 3. Komposisi Nutrien dan Energi Bruto Ransum Perlakuan

\begin{tabular}{|c|c|c|c|c|}
\hline Perlakuan & R0 & R1 & R2 & R3 \\
\hline Ransum Basal (\%) & 100 & 95 & 90 & 85 \\
\hline Tepung daun papaya (TDP) (\%) & 0 & 5 & 10 & 15 \\
\hline Total & 100 & 100 & 100 & 100 \\
\hline \multicolumn{5}{|l|}{ Nutrien / Energi } \\
\hline Protein (\%) & 22,76 & 22,53 & 22,30 & 22,07 \\
\hline Serat Kasar (\%) & 5,82 & 6,170 & 6,51 & 6,85 \\
\hline Lemak Kasar (\%) & 10,57 & 10,12 & 9,68 & 9,23 \\
\hline Kalsium $(\%)$ & 1,05 & 1,22 & 1,40 & 1,57 \\
\hline Phosphor $(\%)$ & 1,04 & 1,01 & 0,98 & 0,94 \\
\hline $\mathrm{EM}(\mathrm{kcal} / \mathrm{kg})$ & 3112,37 & 3055,81 & 3044,12 & 3016,69 \\
\hline
\end{tabular}

Keterangan : dihitung berdasarkan Tabel 1, dan Tabel 2 
ransum, timbangan, kantong plastik penampung ransum perlakuan, alat tulis

Ransum yang digunakan dalam penelitian ini terdiri dari jagung, tepung ikan, tepung kedelai, bungkil kelapa, dedak halus, tepung daun papaya (TDP), top mix dan minyak. Daun pepaya didapat dari perkebunan yang ada di Tanah Putih Atas

Penelitian ini merupakan penelitian eksperimental dengan menggunakan Rancangan Acak Lengkap (Steel and Torrie, 1997) yang terdiri dari 4 perlakuan dan 5 ulangan. Susunan Perlakuan diatur sebagai berikut:

$\mathrm{R}_{0}=$ Ransum Basal 100\% (Tanpa Tepung Daun Pepaya )

$\mathrm{R}_{1}=$ Ransum Basal 95\% $+5 \%$ Tepung Daun Pepaya

$\mathrm{R}_{2}=$ Ransum Basal 90\% $+10 \%$ Tepung Daun Pepaya

$\mathrm{R}_{3}=$ Ransum Basal $85 \%+15 \%$ Tepung Daun Pepaya

Variabel yang diukur pada penelitian ini meliputi:

1.Konsumsi Ransum (gram) diperoleh dari selisih antara jumlah pakan yang diberikan dengan pakan sisa tiap hari.

2.Pertambahan Bobot Badan (gram) yaitu diperoleh dari selisih bobot badan akhir dengan bobot badan awal dibagi lama waktu penelitian. menulis untuk pencatatan data, dan alat kebersihan, (sapu, ember, semprotan). Kecamatan Malalayang. Komposisi nutrien bahan pakan penyusun ransum dapat dilihat pada Tabel 1, sedangkan komposisi ransum basal dilihat pada Tabel 2, serta komposisi nutrien dan energi bruto ransum perlakuan dilihat pada Tabel 3.

3.Konversi pakan dihitung berdasarkan perbandingan antara jumlah rataan konsumsi ransum dengan rataan pertambahan bobot badan per ekor per hari selama penelitian.

\section{HASIL DAN PEMBAHASAN}

\section{Pengaruh Perlakuan Terhadap Konsumsi Ransum}

Rataan konsumsi ransum per ekor per hari selama penelitian dapat dilihat pada Tabel 4. Konsumsi ransum berkisar antara 83,88 - 91,87 g/ekor/hari. Rataan konsumsi ransum tertinggi terdapat pada perlakuan tanpa penggunaan TDP $\left(\mathrm{R}_{0}\right)$ dan terendah pada ransum yang menggunakan tepung daun pepaya sebesar $15 \%\left(\mathrm{R}_{3}\right)$. Kisaran rataan konsumsi ransum pada penelitian ini masih berada pada kisaran yang dinyatakan Manalip et al. (2018) bahwa konsumsi ransum ayam pedaging yaitu 87,05 - 87,73 gram/ekor/hari. 
Tabel 4. Rataan Konsumsi Ransum, Pertambahan Bobot Badan, dan Konversi Ransum Ayam Pedaging Setiap Perlakuan (gram/ ekor/ hari)

\begin{tabular}{lcccc}
\hline \multirow{2}{*}{ Parameter } & \multicolumn{4}{c}{ Perlakuan } \\
\cline { 2 - 5 } & R0 & R1 & R2 & R3 \\
\hline Konsumsi Ransum (g/ekor/hari) & $91,87^{\mathrm{a}}$ & $88,84^{\mathrm{ab}}$ & $87,83^{\mathrm{b}}$ & $83,88^{\mathrm{c}}$ \\
PBB (g/ekor/hari & $38,15^{\mathrm{a}}$ & $35,88^{\mathrm{b}}$ & $33,25^{\mathrm{c}}$ & $32,77^{\mathrm{c}}$ \\
Konversi Ransum & $2,41^{\mathrm{a}}$ & $2,48^{\mathrm{ab}}$ & $2,64^{\mathrm{c}}$ & $2.56^{\mathrm{bc}}$ \\
\hline
\end{tabular}

Keterangan : Superskrip yang berbeda pada baris yang sama menunjukkan perbedaan yang nyata $(\mathrm{P}<0,05)$

Hasil analisis keragaman, menunjukkan bahwa pengaruh penggantian sebagian ransum basal menggunakan tepung daun pepaya dalam ransum memberikan pengaruh berbeda nyata $(\mathrm{P}<0,05)$ terhadap konsumsi ransum. Hasil uji beda nyata jujur (BNJ), menunjukkan bahwa perlakuan R0 berbeda nyata $(\mathrm{P}<0,05)$ lebih tinggi dari pada $\mathrm{R} 2$, dan $\mathrm{R}$, namun tidak berbeda nyata $(\mathrm{P}>0,05)$ dengan R1. Sedangkan perlakuan R1 sama dengan R2 namun berbeda dengan R3 dan perlakuan R2 berbeda dengan R3.

Berdasarkan hasil ini dapat dinyatakan bahwa penggantian ransum basal dengan tepung daun pepaya hanya dapat digunakan sampai 5\%. Hasil ini sejalan dengan penelitian Yunita et al, (2014) bahwa Pemberian tepung daun pepaya dalam ransum puyuh petelur pada taraf $4 \%$ dapat meningkatkan konsumsi ransum, konversi ransum, tetapi pada taraf 6\% dapat menurunkan konsumsi dan konversi ransum. Menurut (Bota, 2007) penambahan tepung daun pepaya sebanyak $6 \%$ dalam ransum komersial memberikan pengaruh terhadap konsumsi ransum, berat badan, dan peningkatan konversi ransum pada ayam petelur jantan.

Pemberian tepung daun pepaya yang semakin tinggi mengakibatkan penurunan konsumsi ransum. Hal ini diduga karena penggunaan daun pepaya yang memilki senyawa alkaloid carpain sehingga menyebabkan perubahan palatabilitas ransum. Situmorang et al. (2013) menyatakan palatabilitas merupakan salah satu faktor yang dapat mempengaruhi konsumsi pakan. Amrullah (2004) menyatakan bahwa konsumsi ransum dapat dipengaruhi oleh beberapa faktor yaitu rasa, bau dan warna ransum. Pada hasil penelitian ini semakin tinggi level pemberian ransum atau pemberian tepung daun pepaya maka semakin gelap warna ransum, sehingga menyebabkan rendahnya konsumsi ransum. Rasyaf (2007) menjelaskan bahwa ransum yang 
berwarna terang lebih disukai unggas dari pada ransum yang berwarna gelap.

\section{Pengaruh Perlakuan Terhadap Pertambahan Berat Badan}

Rataan pertambahan bobot badan ayam pedaging selama penelitian dapat dilihat pada Tabel 4. Pertambahan bobot berkisar antara 32,77 - 38,15 g/ekor/hari. Rataan bobot badan ayam pedaging tertinggi diperoleh pada perlakuan tanpa menggunakan tepung daun pepaya. Kisaran pertambahan bobot badan pada penelitian ini berada dalam kisaran hasil penelitian Nuraga et al. (2018), yaitu 29,73 - 43,31 gram/ekor/hari. Apabila dilihat pada Tabel 4 , pertambahan bobot badan berkisar antara 32,77 - 38,15 g/ekor/hari.

Hasil analisis keragaman menunjukkan bahwa pengaruh penggantian sebagian ransum basal menggunakan tepung daun pepaya dalam ransum memberikan pengaruh berbeda nyata $(\mathrm{P}<0,05)$ terhadap pertambahan bobot badan. Hasil uji beda nyata jujur (BNJ), menunjukkan bahwa perlakuan R0 berbeda nyata $(\mathrm{P}<0,05)$, lebih tinggi dari pada perlakuan R1, R2, dan R3. Sedangkan antara perlakuan R2, dan R3 tidak terdapat perbedaan $\quad(\mathrm{P}>0,05)$. Rendahnya pertambahan bobot ayam pada penelitian ini disebabkan daun pepaya memiliki faktor pembatas yaitu tanin yang merupakan zat anti nutrisi yang dapat mempengaruhi fungsi asam amino dan kegunaan dari protein. Sedikitnya ransum yang dikonsumsi oleh ternak, dikarenakan jumlah konsumsi nutrien tercerna yang berbeda dapat mempengaruhi bobot badan ayam. Hal ini ditunjang oleh Yulman et al. (2014) yang menyatakan bahwa rendahnya pertambahan bobot badan disebabkan oleh konsumsi pakan yang rendah atau sedikit, sehingga kebutuhan nutrisi ayam belum tercukupi. Kiha et al. (2012) menyatakan bahwa faktor - faktor yang mempengaruhi bobot badan ayam pedaging adalah jumlah konsumsi ransum dan kandungan nutrisi yang terdapat dalam pakan.

\section{Pengaruh Perlakuan Terhadap Konversi Ransum}

Rataan konversi ransum ayam pedaging selama penelitian dapat dilihat pada Tabel 4, berkisar antara 2,41 - 2,64. Hasil penelitian ini sejalan dengan penelitian Djapili et al. (2016), bahwa rataan konversi berkisar antara 2,62 - 3,09.

Hasil analisis keragaman menunjukkan bahwa pengaruh penggantian sebagian ransum basal menggunakan tepung daun pepaya dalam ransum memberikan pengaruh berbeda nyata $(\mathrm{P}<0.05)$ terhadap konversi ransum. Hasil uji beda nyata jujur (BNJ), menunjukkan angka konversi ransum perlakuan R0 berbeda nyata $(\mathrm{P}>0,05)$ lebih rendah dari R2 dan R3, namun sama dengan R1. 
Sedangkan perlakuan R2 berbeda dengan R0 dan R1, namun sama dengan R3.

Konversi pakan merupakan salah satu tolak ukur untuk menilai tingkat efisiensi penggunaan pakan. Jika nilai konversi pakan yang ditunjukkan tinggi maka efisiensi penggunaan pakan rendah Sebaliknya jika nilai konversi pakan rendah, maka efisiensi penggunaan pakan tinggi atau baik atau semakin tinggi angka konversi ransum menunjukkan tingkat efisiensi ransum yang rendah, sebaliknya semakin rendah angka konversi ransum menunjukkan tingkat efisiensi lebih tinggi. Pada hasil penelitian ini semakin tinggi ransum tepung daun pepaya maka semakin tinggi juga angka konversi ransum, hal ini menunjukkan semakin rendah kemampuan ternak ayam pedaging dengan mengkonversi ransum menjadi daging. Menurunnya nilai konversi pakan pada penelitian ini disebabkan oleh pertambahan bobot badan dan konsumsi ransum menurun. Menurut Kartasudjana dan Suprijatna (2006) bahwa konversi ransum sangat dipengaruhi oleh konsumsi dan pertambahan bobot badan. Faktor yang mempengaruhi konversi ransum adalah kualitas Day Old Chik (DOC), kualitas nutrisi, manajemen pemeliharaan dan kualitas kandang (Andriyanto et al,. 2015).

\section{KESIMPULAN}

Berdasarkan hasil penelitian bahwa penggunaan tepung daun pepaya dapat menggantikan sebagian ransum sebesar 5\% dalam ransum ayam pedaging.

\section{DAFTAR PUSTAKA}

Amrullah, I. K. 2004. Nutrisi Ayam Petelur. Cetakan ke-3. Bogor. Lembaga Satu Gunung Budi.

Andriyanto., A. S. Satyaningtijas, R. Yufiadri, R. Wulandari, V. M. Darwin, dan S. N. A. Siburi. 2015. Performan dan kecernaan pakan ayam broiler yang diberi hormon testosteron dengan dosis bertingkat. J. Acta Veterinaria Indonesiana $3(1): 29-37$.

Bota, B.J. 2007. Pengaruh Penambahan Tepung Daun Pepaya (Carica papaya L) dalam Pakan Komersil terhadap Konsumsi Pakan, Pertambahan Bobot Badan, dan Konversi Pakan pada Ayam Pedaging Jantan. Undergraduate Tesis Airlangga University Library, Surabaya.

Djapili, D., F. R. Wolayan, I. M. Untu, dan H. Liwe. 2016. Pengaruh penggantian sebagian jagung dengan tepung kulit pisang raja (Musa Paradisiaca) dalam ransum terhadap performans broiler. Zootec 36(1): $158-166$.

Kartasudjana, R., E. Suprijatna. 2006. Manajemen Ternak Unggas. Cetakan Pertama. Penebar Swadaya. Jakarta.

Kiha, A. F., W. Murningsih, Tristiarti. 2012. Pengaruh pemeraman ransum dengan sari daun pepaya terhadap kecernaan lemak dan energi 
metabolis ayam broiler. Animal Agricultural Journal 1(1):265-276.

Manalip, O. M., M. Najoan, M. R. Imbar, dan Y. H. S. Kowel 2018. Penggatian sebagian jagung dengan tepung batang pisang goroho (Musa acuminate sp) dalam ransum terhadap performans broiler. Zootec 38(2): $296-305$

Nuraga, Y. A., F. N. Sompie, Y. H. S. Kowel, dan M. N. Regar. 2018. Pengaruh penggantian sebagian jagung dengan silase kulit pisang kepok (musa paradisiaca formatypica) dalam ransum terhadap performans ayam broiler. Zootec 38(1): 244 - 252.

Rasyaf, M. 2007. Beternak Ayam Broiler. Jakarta: Penebar Swadaya.

Salombre, V.J., M. Najoan, F.N. Sompie, dan M.R. Imbar. 2018. Pengaruh penggunaan silase kulit pisang kepok (Musa paradisiaca formatypica) sebagai pengganti sebagian jagung terhadap karkas dan viscera broiler. Zootec 38(1): 27-36.

Situmorang N. A., L.D. Mahfudz, dan U. Atmomarsono. 2013. Penagaruh
Pemberian tepung rumput laut (gracilaria verrucosa) dalam ransum terhadap efisiensi penggunaan protein ayam broiler. Journal Peternakan 2(2):49-56

Steel, R. G. D. dan J. H. Torrie. 1997. Prinsip dan Prosedur Statistika : Suatu Pendekatan Biometrik. Terjemahan B. Sumantri. Gramedia Pustaka Utama, Jakarta.

Yulman, E. Y., R. Muryani, L.D. Mahfudz. 2014. Performa ayam broiler yang diberi ransum mengandung rumput laut (gracilaria verrucosa) fermentasi. Animal Agricultural Journal 3(2):106-112.

Yunita, R., Wartono, T. Suteky. 2014. Pengaruh pemberian tepung daun pepaya (Carica papaya) dalam ransum terhadap performans produksi telur puyuh (Coturnix coturnix japonica). J. Sain Peternakan Indonesia 9(1): 41-50 